\title{
Communication Crossroads
}

\author{
Brown JF*, Hamilton-Mason J, Maramaldi P and Barnhill LJ
}

Submission: October 09, 2017; Published: November 20, 2017

*Corresponding author: Brown JB, Skills System, P.0. Box 3237, Westport, MA 02790, USA, Tel: 508-636-2603; Email: jbrown@skillssystem.com

\section{Introduction}

Brown et al. [1] conducted a constructivist grounded theory qualitative study that examined perspectives of individuals with dual-diagnosis and histories of challenging behaviors (CB) about their family relationships. The original study included thirty individuals diagnosed with

a. Moderate or mild intellectual disability (ID).

b. Comorbid mental health issues, and

c. Histories of CBs who were divided into five focus groups to discuss their perceptions about relationships.

This review will present observations about how intragroup communication patterns impacted the demonstration of cognitive strengths by participants in the focus group setting.

\section{Discussion}

Although participants demonstrated multiple cognitive strengths during the focus group discussions (e.g. selfawareness, social awareness, insight, wisdom, and spirituality), communication challenges impacted both the expressive and receptive experiences of cognitive strength between focus group participants. For example, participants often had difficulties communicating abstract concepts; they tended to

a. Shifting from associated but divergent abstract topics without transitions.

b. Use fragmented/partial sentences to express abstract concepts.

c. Expressing abstract concepts using concrete language, and

d. Address multiple abstract concepts at one time.

Difficulties related to using proper grammar, organizing disclosures in a linear pattern, and speech impediments impact both the speakers and listeners related to points being made.

The research team observed that within the focus group environment participants (including the facilitator) experienced increased cognitive load demands [2] that impacted intra-group communication. Factors that commonly increase cognitive load demands included simultaneous processing, emotional content, new information, and transitions without orientation [3]. These types of demands were present within the focus group environment, especially as abstract/multi-component topics and increasingly personal disclosures were addressed.

Transactional communication patterns. There appeared to be transactional or bi-directional patterns related to communication difficulties and the expression of cognitive strengths. For example, when the cognitive load increased for the speaker (e.g. attempting to communicate more complex concepts or perspectives involving emotional content), statements tended to become more cryptic and unclear, increasing the cognitive load for the listener. The speaker appeared to understand the multifaceted and abstract concepts, yet had difficulty communicating them in ways that facilitated comprehension for the listener.

The speakers' and listeners' responses appeared to impact whether participants demonstrated cognitive strengths. For example, when the participant or listener prompted clarification, collaborative communication and positive transactions that contained various types of cognitive strengths ensued. If communication problems were unaddressed, it appeared that participants expressed low confidence, deferred to the listeners' inaccurate interpretations, or withdrew from the conversation. Throughout the focus groups, participants and the facilitator continually navigated communication crossroads, both actively assessing whether it was beneficial to seek clarification or to move on.

\section{Conclusion}

This review highlighted several interesting observations about bi-direction communication patterns, cognitive load, and cognitive strengths that may be worth deeper exploration using more rigorous methods. For example, individuals with moderate or mild ID may have difficulty effectively communicating their complex perspectives, especially to listeners who are not supplying scaffolding that promotes positive communication transactions. The idea that participants may have complex 
insights, but their abilities to articulate them may be lacking, is different than a perspective that individuals with ID lack insight and cannot understand abstract concepts.

Misattributing communication challenges and executive functioning difficulties that influence the transfer of personal perspectives as a lack of globalized intrinsic capacity may fuel power differentials on a micro-level and marginalization of this population on a macro-level. It possible that break-downs within bi-directional communication patterns contribute this populations' vulnerability to mental health problems, as well as, CBs. A better understanding of positive and negative communication transactions may lead support staff and mental health practitioners to provide communication scaffolding to individuals with ID to help maximize the demonstration of cognitive strengths and reduce CBs.

\section{References}

1. Brown JF, Hamilton-Mason J, Maramaldi P, Barnhill LJ (2016) Exploring perspectives of individuals with intellectual disabilities and histories of challenging behaviors: An emergent topic in a grounded theory focus group study. Journal of Mental Health Research in Intellectual Disabilities 9(3): 133-156.

2. Sweller J (1988) Cognitive load during problem solving: Effects on learning. Cognitive Science 12: 257-285.

3. Sweller J (2010) Element interactivity and intrinsic, extraneous, and germane cognitiveload. Educational Psychology Review 22(2): 123138.

\section{Your next submission with Juniper Publishers will reach you the below assets}

- Quality Editorial service

- Swift Peer Review

- Reprints availability

- E-prints Service

- Manuscript Podcast for convenient understanding

- Global attainment for your research

- Manuscript accessibility in different formats

( Pdf, E-pub, Full Text, Audio)

- Unceasing customer service

Track the below URL for one-step submission

https://juniperpublishers.com/online-submission.php 